
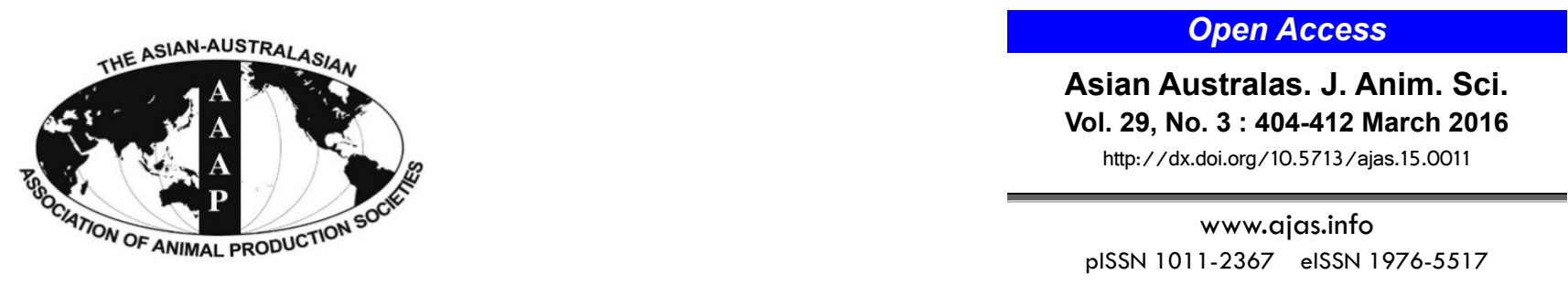

\title{
The Expression of Adipogenic Genes in Adipose Tissues of Feedlot Steers Fed Supplementary Palm Oil or Soybean Oil
}

\author{
Seong Ho Choi ${ }^{\mathrm{a}}$, Sung Kwon Park ${ }^{1, a}$, Chang Weon Choi ${ }^{2}$, Xiang Zi Li ${ }^{3}$, Kyoung Hoon Kim \\ Won Young Kim, Joon Jeong ${ }^{5}$, Bradley J. Johnson ${ }^{6}$, Linsen Zan ${ }^{7}$, and Stephen B. Smith ${ }^{8, *}$ \\ Department of Animal Science, Chungbuk National University, Cheongju 362-763, Korea
}

\begin{abstract}
We hypothesized that supplementing finishing diets with palm oil would promote adipogenic gene expression and stearoyl-CoA desaturase $(S C D)$ gene expression in subcutaneous (s.c.) and intramuscular (i.m.) adipose tissues of feedlot steers. Eighteen Angus and Angus crossbred steers were assigned to three groups of 6 steers and fed a basal diet (control), with 3\% palm oil, or with $3 \%$ soybean oil, for $70 \mathrm{~d}$, top-dressed daily. Tailhead s.c. adipose tissue was obtained by biopsy at $14 \mathrm{~d}$ before the initiation of dietary treatments and at $35 \mathrm{~d}$ of dietary treatments. At slaughter, after $70 \mathrm{~d}$ of dietary treatment, tailhead s.c. adipose tissue and i.m. adipose tissue were obtained from the longissimus thoracis muscle. Palm oil increased plasma palmitic acid and soybean oil increased plasma linoleic acid and $\alpha$-linolenic acid relative to the initial sampling time. Expression of AMP-activated protein kinase alpha $(A M P K \alpha)$ and peroxisome proliferator-activated receptor gamma $(P P A R \gamma)$ increased between the initial and intermediate biopsies and declined thereafter $(\mathrm{p}<0.03)$. $S C D$ gene expression did not change between the initial and intermediate biopsies but declined by over $75 \%$ by the final period $(\mathrm{p}=0.04)$, and G-coupled protein receptor $43(G P R 43)$ gene expression was unaffected by diet or time on trial. Soybean oil decreased $(\mathrm{p}=0.01) P P A R \gamma$ gene expression at the intermediate sample time. At the terminal sample time, $P P A R \gamma$ and $S C D$ gene expression was less in i.m. adipose tissue than in s.c. adipose tissue $(\mathrm{p}<0.05)$. $A M P K \alpha$ gene expression was less in s.c. adipose tissue of palm oil-fed steers than in control steers $(\mathrm{p}=0.04)$ and CCAAT enhancer binding protein-beta $(C E B P \beta)$ gene expression was less in s.c. and i.m. adipose tissues of palm oil-fed steers than in soybean oil-fed steers $(\mathrm{p}<0.03)$. Soybean oil decreased $S C D$ gene expression in s.c. adipose tissue $(\mathrm{p}=0.05) ; S C D$ gene expression in palm oil-fed steers was intermediate between control and soybean oil-fed steers. Contrary to our original hypothesis, palm oil did not promote adipogenic gene expression in s.c. and i.m. adipose tissue. (Key Words: Adipose Tissue, Fatty Acids, Gene Expression, Palm Oil, Stearoyl-coenzyme A Desaturase)
\end{abstract}

\section{INTRODUCTION}

Foods high in oleic acid (18:1n-9), including oleic acid-

\footnotetext{
* Corresponding Author: Stephen B. Smith. E-mail: sbsmith@tamu.edu

${ }^{1}$ Department of Food Science and Technology, Sejong University, Seoul 143

747 , Korea.

2 Department of Animal Resources, Daegu University, Gyeongsan 712-714, Korea.

${ }^{3}$ Department of Animal Science, Yanbian University, Yanji 133002, China.

${ }^{4}$ Graduate School of International Agricultural Technology, and Institute of Green Bio Science \& Technology, Seoul National University, Seoul National University, Pyeongchang 232-916, Korea.

${ }^{5}$ Livestock Research Center, National Agricultural Cooperatives Federation, Anseong 456-824, Korea.

${ }^{6}$ Department of Animal and Food Science, Texas Tech University, Lubbock, TX 79409, USA.

7 Department of Animal Science, Northwest Agricultural and Forestry University, Yangling 712100, China.

${ }^{8}$ Department of Animal Science, Texas A\&M University, College Station, TX 77843, USA.

a Seong Ho Choi and Sung Kwon Park equally contributed as first author.

Submitted Jan. 6, 2015; Revised Mar. 22, 2015; Accepted May 20, 2015
}

enriched beef, reduce risk factors for cardiovascular disease (Adams et al., 2010; Gilmore et al., 2011;2013). Higher concentrations of oleic acid also are positively correlated with overall palatability of beef (Westerling and Hedrick, 1979), whereas increased stearic acid (18:0) is the primary determinant of fat hardness (i.e., lipid melting point; Smith et al., 1998). Therefore, increasing monounsaturated fatty acids (MUFA) and decreasing saturated fatty acid (SFA) would increase healthfulness, palatability, and fat softness of animal products. The conversion of SFA to MUFA by the fatty acid $\Delta^{9}$ desaturase, stearoyl-CoA desaturase, accounts for the majority of MUFA in muscle and adipose tissues, i.e., the edible portions of beef carcasses (St. John et al., 1991; Duckett et al., 2009). Stearoyl-CoA desaturase (SCD) is encoded by the $S C D$ gene, and previous studies have indicated that SCD gene expression and/or SCD activity is elevated in adipose tissues containing a high concentration 
of MUFA (Archibeque et al., 2005; Chung et al., 2007; Duckett et al., 2009).

We recently demonstrated that the SFA palmitic acid (16:0) and stearic acid (18:0) strongly promoted CCAAT enhancer binding protein-beta $(C E B P \beta)$ and carnitinepalmitoyl-CoA transferase-1beta $(C P T 1 \beta)$ gene expression in intramuscular (i.m.) preadipocytes (Choi et al., 2015). Conversely, the MUFA oleic acid (18:1cis-9) and the polyunsaturated fatty acids (PUFA) linoleic (18:2n-6) and $\alpha$-linolenic acid (18:3n-3) depressed $S C D$ gene expression. Therefore, we hypothesized that supplementing the diets of beef cattle with palm oil, rich in palmitic acid, would increase adipogenic gene expression in subcutaneous (s.c.) and i.m. adipose tissues. We previously demonstrated that, relative to soybean oil, feeding $3 \%$ palm oil to cattle increased s.c. adipocyte size and the activities of nicotinamide adenine dinucleotide phosphate (NADP)malate dehydrogenase and glucose-6-phosphate dehydrogenase (Choi et al., 2013). Additionally, palm oil, which also is rich in oleic acid, decreased the ratio of palmitoleic acid (16:1n-7) to stearic acid (an index of SCD activity), so we further hypothesized the palm oil would decrease $S C D$ gene expression. Soybean oil also was tested because it is rich in PUFA and also would be expected to decrease $S C D$ gene expression.

In this study, we documented specific gene expression in s.c. and i.m. adipose tissue depots over the period of time when steers typically accumulate carcass adipose tissue, carnitine, and the genes $C E B P \beta, S C D$, peroxisome proliferator-activated receptor gamma $(P P A R \gamma)$, AMPactivated protein kinase alpha $(A M P K \alpha)$, and G-coupled protein receptor 43 (GPR43) were selected as genetic markers of adipose tissue differentiation. The $C E B P \beta$ gene product is involved in adipocyte proliferation, metabolism, and differentiation, and binds to promoter regions of adipogenic genes (Cao et al., 1991). Similarly, the PPAR $\gamma$ gene product is required for proper adipose tissue development (Tontonoz et al., 1994) and is expressed abundantly in differentiating bovine adipocytes (Smith et al., 2009). AMPK $\alpha$ activity inactivates energy-consuming processes such as fatty acid biosynthesis, while activating energy-producing processes such as fatty acid oxidation (Hardie, 2007). In response to activation by volatile fatty acids, GPR43 activates cellular responses that subsequently depress triacylglycerol turnover (Hardie, 2007), thereby promoting adiposity. Acetate and propionate activate the GPR43 receptor (Brown et al., 2003), which leads to a reduction in lipolysis (Ge et al., 2008). This in turn increases lipid accumulation in adipocytes and promotes metabolism of fatty acids and glucose in other tissues (Kimura et al., 2013). These effects may be attenuated by $A M P K \alpha$ (Yin et al., 2003), as expression of $A M P K \alpha$ promotes fatty acid oxidation by up-regulating $P P A R \gamma$ coactivator-1alpha ( $P G C-1 \alpha)$ gene expression (Wan et al., 2014). Because palm oil increases carcass adiposity and lipogenesis in s.c. adipose tissue (Choi et al., 2013), we hypothesized that palm oil would increase the expression of genes associated with adipogenesis $(C E B P \beta, P P A R \gamma$, $G P R 43$, and $S C D$ ), and decrease $A M P K \alpha$ gene expression. We specifically investigated the effects of palm and soybean oil on adipose tissue depots because s.c. adipose tissue is readily accessible by biopsy technique, and because both s.c. and i.m. adipose tissues are important components of beef and beef products.

\section{MATERIALS AND METHODS}

\section{Study design}

The experimental procedures were approved by the Texas A\&M University Animal Care and Use Committee, Office of Research Compliance. We previously reported carcass quality, fatty acid composition, and de novo fatty acid synthesis in s.c. adipose tissue taken at slaughter in this same group of cattle (Choi et al., 2013). Briefly, 15 Angus and 13 Angus $\times$ Brahman crossbred steers from the Texas A\&M University Research Center at McGregor, TX were grazed on native pasture until 12 mo of age. Steers were assigned to three groups of 9 or 10 steers at an average body weight (BW) of $364.5 \pm 7.6 \mathrm{~kg}$. Steers were blocked by breed type, stratified by BW, and assigned randomly to dietary treatments within block and strata, such that resultant treatment groups consisted of 5 Angus steers and 4 to 5 Angus $\times$ Brahman crossbred steers, balanced for BW. Steers were adapted to a corn/milo finishing diet (Table 1) and Calan gates over a 14-d period and then fed the finishing diet free choice until they achieved a BW of $473.6 \pm 7.9 \mathrm{~kg}$ (approximately $15 \mathrm{mo}$ of age). Steers then were fed the basal diet without additional fat (control), the basal diet with 3\% palm oil, or the basal diet with 3\% soybean oil, added as top dressings. The palm oil contained $43.6 \%$ palmitic acid, $4.6 \%$ stearic acid, $37.1 \%$ oleic acid, $10.4 \%$ linoleic acid, and $0.2 \% \alpha$-linolenic acid. The soybean oil contained $10.7 \%$ palmitic acid, $4.6 \%$ stearic acid, $22.8 \%$ oleic acid, 51.8\% linoleic acid, and 6.9\% $\alpha$-linolenic acid. When mixed with the basal diet, the palm oil diet contained $20.4 \mathrm{~g} / \mathrm{kg}$ palmitic acid and $21.1 \mathrm{~g} / \mathrm{kg}$ oleic acid and the soybean oil diet contained $16.1 \mathrm{~g} / \mathrm{kg}$ oleic acid, $28.9 \mathrm{~g} / \mathrm{kg}$ linoleic acid, and $2.6 \mathrm{~g} / \mathrm{kg} \alpha$-linolenic acid (Table 2). Thus, palm oil was considered a source of supplementary palmitic and oleic acid, whereas soybean oil was a source of oleic, linoleic, and $\alpha$-linolenic acid.

Steers were fed the experimental diets for $10 \mathrm{wk}$ until they attained an average body weight of $564.5 \pm 8.0 \mathrm{~kg}$. Biopsy samples of s.c. adipose tissue were taken as described previously (Martin et al., 1999) $14 \mathrm{~d}$ before the initiation of dietary treatment and at $35 \mathrm{~d}$ of dietary 
Table 1. Ingredients and chemical composition of the corn-based, finishing diet of Angus steers

\begin{tabular}{lc}
\hline Variable & Basal (control) diet \\
\hline Ingredients & \\
Ground milo & 20.00 \\
Ground corn & 48.05 \\
Cottonseed meal & 6.00 \\
Cottonseed hulls & 15.00 \\
Molasses & 7.50 \\
Limestone & 0.96 \\
Trace mineralized salt ${ }^{1}$ & 0.56 \\
Dicalcium phosphate & 0.23 \\
Potassium chloride & 0.16 \\
Zinc oxide & 0.01 \\
Ammonium sulfate & 0.25 \\
Vitamin premix ${ }^{2}$ & 0.08 \\
R-1500 & 1.20 \\
Total percentage & 100.00 \\
Nutritional composition $\left(\%\right.$ as fed $\left.^{4}\right)$ & \\
Dry matter & 89.13 \\
Crude protein & 11.16 \\
Calcium & 0.52 \\
Phosphorous & 0.36 \\
Energy content & \\
NEm (Mcal/kg) & 1.78 \\
NEg (Mcal/kg) & 1.17 \\
\hline
\end{tabular}

$\mathrm{NEm}$, net energy of maintenance; NEg, net energy of gain.

${ }^{1}$ Trace mineralized salt: $\mathrm{NaCl}, 98 \%$; $\mathrm{Zn}, 0.35 \%$; Mn $0.28 \%$; Fe, $0.175 \%$; $\mathrm{Cu}, 0.035 \%$; I, $0.007 \%$; Co, $0.0007 \%$.

2 Vitamin premix: vitamin A, 2,200,000 IU/kg; vitamin D, 1,100,000 $\mathrm{IU} / \mathrm{kg}$; vitamin E, 2,200 IU/kg.

${ }^{3} \mathrm{R}-1500: 1.65 \mathrm{~g}$ monensin sodium (Rumensin) per $\mathrm{kg}$.

${ }^{4}$ Calculated values based on NRC (2000)

treatment. Briefly, the area was shaved and washed with iodine solution and ethanol. Three injections of lidocaine were used to anesthetize the area and a triangular flap of skin was lifted and underlying s.c. adipose tissue was removed. The flap was stapled shut and rinsed with $70 \%$

Table 2. Fatty acid content ( $\mathrm{g} / \mathrm{kg}$ feed) of the basal (control) diet and diets containing $3 \%$ added palm oil or $3 \%$ soybean oil

\begin{tabular}{lccc}
\hline \multirow{2}{*}{ Fatty acid } & \multicolumn{3}{c}{ Diet $(\mathrm{g} / \mathrm{kg}$ feed } \\
\cline { 2 - 4 } & Control $^{1}$ & Palm oil $^{2}$ & Soybean oil $^{2}$ \\
\hline $14: 0$ & 0.14 & 0.46 & 0.15 \\
$16: 0$ & 6.53 & 20.45 & 9.75 \\
$16: 1$ cis-9 & 0.12 & 0.17 & 0.14 \\
$18: 0$ & 1.01 & 2.47 & 2.18 \\
$18: 1$ cis-9 & 9.23 & 21.06 & 16.08 \\
$18: 1$ cis-11 & 0.34 & 0.54 & 0.79 \\
$18: 2 \mathrm{n}-6$ & 13.44 & 16.78 & 28.97 \\
$18: 3 \mathrm{n}-3$ & 0.60 & 0.66 & 2.69 \\
\hline
\end{tabular}

${ }^{1}$ Basal diet contained $31.9 \mathrm{~g}$ total $\mathrm{lipid} / \mathrm{kg}$.

${ }^{2}$ Palm oil and soybean oils were added at $3 \%$ of the diet, added as top dressing. ethanol.

After $70 \mathrm{~d}$ of dietary treatment, the steers were transported to and harvested at the Texas A\&M University Rosenthal Meat Science and Technology Center. The 8th to 11th longissimus thoracis rib section was removed immediately after the hide was removed (approximately 20 min postmortem). The entire rib muscle section was placed in oxygenated $37^{\circ} \mathrm{C}$, Kreb Henseleit buffer containing 5 $\mathrm{m} M$ glucose and transported to the laboratory. Intramuscular adipose tissue was dissected from the muscle, snap frozen in liquid nitrogen, and stored at $-80^{\circ} \mathrm{C}$ until used for RNA extraction. Subcutaneous adipose tissue was removed from the tailhead region, adjacent to previous biopsy sites, snap frozen, and stored at $-80^{\circ} \mathrm{C}$.

\section{RNA extraction and real-time polymerase chain reaction}

Gene expression in s.c. and i.m. adipose tissues was measured using the primers as described previously (Smith et al., 2012). Total RNA was extracted with Tri Reagent (Sigma Chemicals, St. Louis, MO, USA), and the concentration of RNA was quantified with a NanoDrop ND-100 Spectrophotometer (Thermo Scientific, Washington, DC, USA). Quantitative real-time polymerase chain reaction (qPCR) was used to analyze the expression of $C E B P \beta, S C D, P P A R \gamma, A M P K \alpha$, and GPR43. Primers used for qPCR are listed in Table 3. The 40S ribosomal protein S9 (RPS9) was used as an endogenous gene expression control. Complementary DNA (cDNA) was produced from $1 \mu \mathrm{g}$ RNA using TaqMan Reverse Transcriptase Reagents (Applied Biosystems, Foster City, CA, USA) by the protocol recommended by the manufacturer. Random hexamers were used as primers in cDNA synthesis. Measurement of the relative quantity of the cDNA of interest was carried out using TAMRA PCR Master Mix (Applied Biosystems, USA), appropriate forward and reverse primers, and $1 \mu \mathrm{L}$ of the cDNA mixture. Assays were performed in the GeneAmp 5700 Sequence Detection System (Applied Biosystems, USA) using thermal cycling parameters recommended by the manufacturer $\left(40\right.$ cycles of $15 \mathrm{~s}$ at $95^{\circ} \mathrm{C}$ and $1 \mathrm{~min}$ at $60^{\circ} \mathrm{C}$ ). Titration of each set of mRNA primers against increasing amounts of cDNA yielded linear responses with slopes between -2.8 and -3.0 . In order to reduce the effect of assay-to-assay variation in the qPCR assay, all values were calculated relative to a calibration standard run on every qPCR assay. Commercially available eukaryotic RPS9 DNA primers and probes were used as an endogenous control (Applied Biosystems, USA; GeneBank Accession \#X03205). The ABI Prism 7000 detection system (Applied Biosystems, USA) was used to perform the assay utilizing the thermal cycling variables recommended by the manufacturer $\left(50\right.$ cycles of $15 \mathrm{~s}$ at $95^{\circ} \mathrm{C}$ and $1 \mathrm{~min}$ at $60^{\circ} \mathrm{C}$ ). 
Table 3. Forward and reserve primers and probes for real-time polymerase chain reaction for specific gene mRNA

\begin{tabular}{|c|c|c|c|}
\hline Maker gene & Gene no. & & Sequence (5' to 3') \\
\hline \multirow[t]{3}{*}{ RPS9 } & DT860044 & Forward & GAGCTGGGTTTGTCGCAAAA \\
\hline & & Reverse & GGTCGAGGCGGGACTTCT \\
\hline & & Taqman probe & 6FAM-ATGTGACCCCGCGGAGACCCTTC-TAMRA \\
\hline \multirow[t]{3}{*}{$A M P K \alpha$} & NM_001109802 & Forward & ACCATTCTTGGTTGCTGAAACTC \\
\hline & & Reverse & CACCTTGGTGTTTGGATTTCTG \\
\hline & & Taqman probe & 6FAM-CAGGGCGCGCCATACCCTTG-TAMRA \\
\hline \multirow[t]{3}{*}{$C E B P \beta$} & NM_176788 & Forward & CCAGAAGAAGGTGGAGCAACTG \\
\hline & & Reverse & TCGGGCAGCGTCTTGAAC \\
\hline & & Taqman probe & 6FAM-CGCGAGGTCAGCACCCTGC-TAMRA \\
\hline \multirow[t]{3}{*}{ GPR43 } & FJ562212 & Forward & GGCTTTCCCCGTGCAGTA \\
\hline & & Reverse & ATCAGAGCAGCGATCACTCCAT \\
\hline & & Taqman probe & 6FAM-AAGCTGTCCCGCCGGCCC-TAMRA \\
\hline \multirow[t]{3}{*}{$P P A R \gamma$} & NM_181024 & Forward & ATCTGCTGCAAGCCTTGGA \\
\hline & & Reverse & TGGAGCAGCTTGGCAAAGA \\
\hline & & Taqman probe & 6FAM-CGCGAGGTCAGCACCCTGC-TAMRA \\
\hline \multirow[t]{3}{*}{$S C D$} & AB075020 & Forward & TGCCCACCACAAGTTTTCAG \\
\hline & & Reverse & GCCAACCCACGTGAGAGAAG \\
\hline & & Taqman probe & 6FAM-CCGACCCCCACAATTCCCG-TAMRA \\
\hline
\end{tabular}

RPS9, ribosomal protein S9; $A M P K \alpha$, AMP-activated protein kinase alpha; $C E B P \beta$, CCAAT enhancer binding protein-beta; GPR43, G-coupled protein receptor 43; $P P A R \gamma$, peroxisome proliferator-activated receptor gamma; $S C D$, stearoyl-CoA desaturase.

\section{Fatty acid composition of the diet and adipose tissue}

Total lipids of the diets $(5 \mathrm{~g})$ and i.m. adipose tissue $(100 \mathrm{mg})$ were extracted and fatty acid methyl esters (FAME) were prepared as described previously (Archibeque et al., 2005). The diets were sampled at three intervals and the data pooled (Table 2). FAME were analyzed by GC-FID (model CP-3800 equipped with a CP8200 auto-sampler; Varian Inc, Palo Alto, CA, USA). Separation of FAME was accomplished on a fused silica capillary column $(100 \mathrm{~m} \times 0.25 \mathrm{~mm}$ ID) (model CP-3800, Varian Inc, USA) with the helium as carrier gas (flow rate $=$ $1.7 \mathrm{~mL} / \mathrm{min}$ ). One microliter of sample was injected with the split ratio of $100: 1$ at $270^{\circ} \mathrm{C}$. Oven temperature was set at $165^{\circ} \mathrm{C}$ for $65 \mathrm{~min}$ and then increased to $235^{\circ} \mathrm{C}\left({ }^{\circ} \mathrm{C} / \mathrm{min}\right)$ and held for $15 \mathrm{~min}$. Flame ionization detector (FID) detected the signal at $270^{\circ} \mathrm{C}$. An authentic standard (GLC 68D, Nu-chek Prep, Waterville, MN, USA) was used to confirm the identity of each peak.

\section{Statistical analyses}

Data were analyzed using the general linear mixed models (GLMM) procedures of IBM SPSS version 20.0 (IBM Co., Armonk, NY, USA) as appropriate for completely randomized designs. The model tested the main effects of diet, time on feed, and the diet $\times$ time on feed interaction. At slaughter, the adipose tissue depot (s.c. vs i.m.), diet, and adipose tissue $\times$ diet effects were tested. Means were separated by the Fisher's protected least significant difference and considered different at $p<0.05$, although trends $(\mathrm{p} \leq 0.10)$ also are discussed.

\section{RESULTS}

Palm oil had no effect on average daily gain (ADG), average daily intake (ADI), or the gain:feed ratio $(G: F)$, whereas soybean oil depressed ADG $(p=0.02)$, ADI $(p=$ $0.04)$ and $G: F(p=0.05)$, relative to control and palm oilfed steers (Table 4). However, final BW $(p=0.19)$ and carcass weight $(p=0.45)$ were unaffected by supplemental dietary oils. Marbling scores tended $(\mathrm{p}<0.09)$ to be different between palm oil-fed steers (Modest ${ }^{09}$ ) and soybean oil-fed steers $\left(\right.$ Small $\left.^{55}\right)$. Neither palm oil nor soybean oil significantly affected 12th thoracic rib fat thickness or kidney, pelvic, and heart fat ( $\mathrm{p} \geq 0.15)$.

The proportion of palmitic acid in plasma increased between the initial and intermediate sampling periods in the palm oil-fed steers (diet $\times$ time $p=0.002)$ (Figure 1$)$. There also was a main diet effect for plasma palmitic acid ( $\mathrm{p}=$ $0.002)$; palmitic acid was highest in palm oil-fed steers and lowest in soybean oil-fed steers. Plasma oleic acid was lowest in the soybean oil-fed steers (diet $p=0.04)$, whereas plasma linoleic acid and $\alpha$-linolenic acid were highest in soybean oil-fed steers at the intermediate and final sampling periods (diet $\times$ time $p=0.05$ and 0.01 , respectively) (Figure 1). Dietary treatment effects were not significant for stearic acid, palmitoleic acid, or cis-vaccenic acid (18:1n-7; $\mathrm{p} \geq 0.17)$ (data not shown in tabular form).

The diet $\times$ time interaction was not significant for any gene measured in this study, so only the main effects of diet, time, and adipose tissue depot are reported. $A M P K \alpha$ and $P P A R \gamma$ gene expression in s.c. adipose tissue increased 
Table 4. Growth and carcass characteristics of feedlot steers fed a basal finishing diet $(\mathrm{n}=10)$ or diets supplemented with $3 \%$ palm oil $(\mathrm{n}$ $=9)$ or $3 \%$ soybean oil $(n=9)$

\begin{tabular}{|c|c|c|c|c|c|}
\hline \multirow{2}{*}{ Item } & \multicolumn{3}{|c|}{ Treatment $^{1}$} & \multirow{2}{*}{ SEM } & \multirow{2}{*}{ p-value } \\
\hline & Control & Palm oil & Soybean oil & & \\
\hline Initial live weight (kg) & 469.5 & 470.9 & 478.2 & 7.9 & 0.29 \\
\hline Final live weight (kg) & 567.7 & 571.4 & 553.6 & 8.0 & 0.19 \\
\hline $\operatorname{ADG}(\mathrm{kg} / \mathrm{d})$ & $1.06^{\mathrm{a}}$ & $1.10^{\mathrm{a}}$ & $0.76^{\mathrm{b}}$ & 0.06 & 0.02 \\
\hline ADI (kg/d) & $10.2^{\mathrm{a}}$ & $10.0^{\mathrm{a}}$ & $9.0^{\mathrm{b}}$ & 0.3 & 0.04 \\
\hline G:F & $0.10^{\mathrm{a}}$ & $0.11^{\mathrm{a}}$ & $0.08^{\mathrm{b}}$ & 0.01 & 0.05 \\
\hline Marbling score $^{1}$ & 479.0 & 508.9 & 455.6 & 14.1 & 0.09 \\
\hline 12th rib fat thickness $(\mathrm{cm})$ & 1.87 & 1.95 & 1.72 & 0.09 & 0.16 \\
\hline Ribeye area $\left(\mathrm{cm}^{2}\right)$ & 81.8 & 81.1 & 80.8 & 1.2 & 0.37 \\
\hline КРН (\%) & 2.30 & 2.61 & 2.50 & 0.12 & 0.15 \\
\hline
\end{tabular}

SEM, standard error of the mean; ADG, average daily gain; ADI, average daily intake; G:F, gain:feed ratio; KPH, kidney, pelvic, and heart fat.

${ }^{1}$ Marbling score: 400 , small; 500, modest.

${ }^{\mathrm{ab}}$ Means in rows not bearing a common superscript differ, $\mathrm{p}<0.05$.
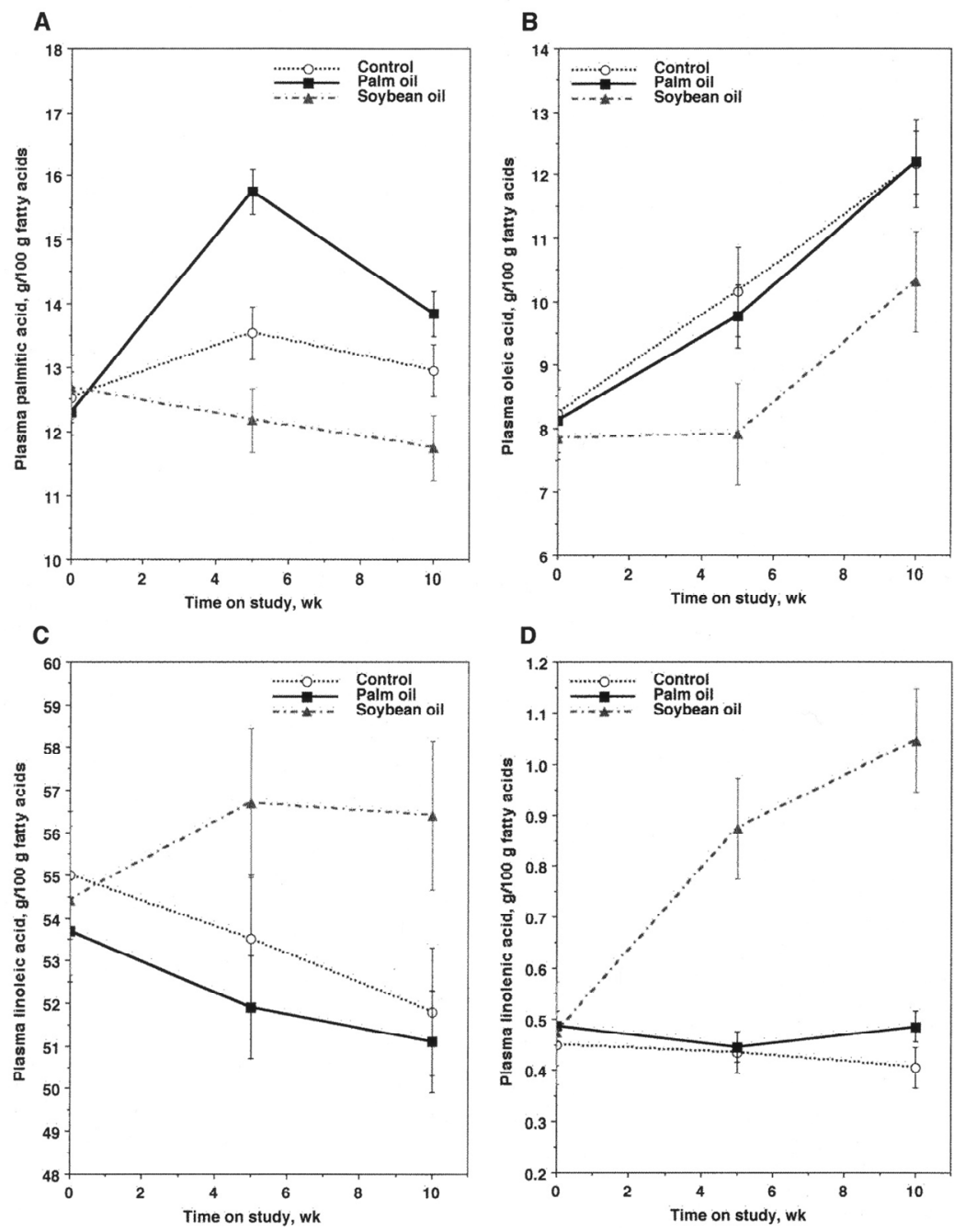

Figure 1. Plasma palmitic acid (A), oleic acid (B), linoleic acid (C), and $\alpha$-linolenic acid (D) in steers fed a corn-based, control diet or the corn-based diet containing $3 \%$ palm oil or $3 \%$ soybean oil. $p$-values: (A) diet $p=0.002$, time $p=0.001$, diet $\times$ time $p=0.002$; (B) diet $\mathrm{p}=0.04$, time $\mathrm{p}=0.0001$, diet $\times$ time $\mathrm{p}=0.38 ;(\mathrm{C}) \operatorname{diet} \mathrm{p}=0.004$, time $\mathrm{p}=0.24$, diet $\times$ time $\mathrm{p}=0.05 ;(\mathrm{D})$ diet $\mathrm{p}=0.001$, time $\mathrm{p}=0.06$, diet $\times$ time $\mathrm{p}=0.01$. 
Table 5. Gene expression in biopsy samples of tailhead subcutaneous adipose tissue (initial, d-14; intermediate, d 35) and tailhead subcutaneous adipose tissue taken at slaughter (d 70) (data pooled across diets)

\begin{tabular}{lccccc}
\hline \multirow{2}{*}{ Gene } & \multicolumn{3}{c}{ Day $^{1}$} & \multirow{2}{*}{ SEM } & p-value \\
\cline { 2 - 4 } & $\mathrm{d}-14$ & $\mathrm{~d} \mathrm{35}$ & $\mathrm{d} \mathrm{70}$ & & \\
\hline$A M P K \alpha$ & $1.58^{\mathrm{b}}$ & $4.44^{\mathrm{a}}$ & $2.09^{\mathrm{b}}$ & 0.43 & 0.01 \\
$C E B P \beta$ & 1.35 & 1.69 & 1.78 & 0.22 & 0.16 \\
GPR43 & 3.81 & 1.66 & 3.12 & 0.54 & 0.12 \\
$P P A R \gamma$ & $2.86^{\mathrm{b}}$ & $9.44^{\mathrm{a}}$ & $1.10^{\mathrm{b}}$ & 1.10 & 0.01 \\
$S C D$ & $2.45^{\mathrm{a}}$ & $2.89^{\mathrm{a}}$ & $0.86^{\mathrm{b}}$ & 0.36 & 0.04 \\
\hline
\end{tabular}

$A M P K \alpha$, AMP-activated protein kinase alpha; $C E B P \beta$, CCAAT enhancer binding protein-beta; GPR43, G-coupled protein receptor 43; PPAR , peroxisome proliferator-activated receptor gamma; $S C D$, stearoyl-CoA desaturase.

${ }^{1}$ Initial, $14 \mathrm{~d}$ prior to initiating feeding trial; Intermediate, $35 \mathrm{~d}$ on feeding trial; Slaughter, $70 \mathrm{~d}$ on feeding trial.

${ }^{a b}$ Means in rows not bearing a common superscript differ, $\mathrm{p}<0.05$.

between the initial and intermediate biopsies and declined thereafter $(\mathrm{p}=0.01$; data pooled across diets) (Table 5). $S C D$ gene expression did not change between the initial and intermediate s.c. adipose tissue biopsies but declined by over $75 \%$ between the intermediate and final periods $(\mathrm{p}=$ $0.04)$. There were no differences across time on study for $C E B P \beta$ or GPR 43 gene expression.

At the intermediate sampling period (d 35), soybean oil decreased PPAR $\gamma$ gene expression (Table 6). Palm oil tended $(\mathrm{p}=0.08)$ to increase $A M P K \alpha$ gene expression. Neither palm oil nor soybean oil affected $C E B P \beta, G P R 43$, or $S C D$ gene expression at the intermediate sampling period
Table 6. Diet main effects for gene expression in subcutaneous adipose tissue of feedlot steers fed a basal finishing diet $(n=6)$ or the basal diet supplemented with $3 \%$ palm oil $(n=6)$ or $3 \%$ soybean oil $(n=6)$ for $35 d$ (intermediate sample)

\begin{tabular}{lccccc}
\hline \multirow{2}{*}{ Gene } & \multicolumn{3}{c}{ Treatment } & \multirow{2}{*}{ SEM } & p-value \\
\cline { 2 - 5 } & Control & Palm oil & Soybean oil & & \\
\hline$A M P K \alpha$ & 4.30 & 6.65 & 2.82 & 0.90 & 0.08 \\
$C E B P \beta$ & 1.17 & 2.46 & 1.37 & 0.35 & 0.17 \\
$G P R 43$ & 3.47 & 1.05 & 0.91 & 0.65 & 0.15 \\
$P P A R \gamma$ & $13.21^{\mathrm{a}}$ & $13.84^{\mathrm{a}}$ & $2.91^{\mathrm{b}}$ & 2.11 & 0.01 \\
$S C D$ & 3.25 & 2.39 & 3.01 & 0.68 & 0.31 \\
\hline
\end{tabular}

$A M P K \alpha$, AMP-activated protein kinase alpha; $C E B P \beta$, CCAAT enhancer binding protein-beta; GPR43, G-coupled protein receptor 43; PPAR $\gamma$, peroxisome proliferator-activated receptor gamma; $S C D$, stearoyl-CoA desaturase.

${ }^{\mathrm{ab}}$ Means in rows not bearing a common superscript differ, $\mathrm{p}<0.05$.

$(\mathrm{p} \geq 0.15)$. However, $C E B P \beta$ gene expression was numerically lowest in s.c. adipose tissue of the soybean oilfed steers, which was consistent with the low level of PPAR $y$ gene expression observed adipose tissue of the soybean oil-fed steers.

There were greater proportions of SFA in i.m. adipose tissue and correspondingly lesser proportions of MUFA in i.m. adipose tissue, relative to s.c. adipose tissue (Table 7). Palm oil decreased palmitoleic acid in s.c. adipose tissue and a similar tendency was observed in i.m. adipose tissue $(\mathrm{p}=0.10)$. Similarly, the lowest proportion of cis-vaccenic acid was observed in s.c. and i.m. adipose tissues of palm oil-fed steers $(\mathrm{p} \leq 0.04)$. Intramuscular adipose tissue of soybean oil-fed steers tended $(\mathrm{p}=0.10)$ to have a greater

Table 7. Tissue and diet effects for fatty acid composition and gene expression in subcutaneous and intramuscular adipose tissues taken at slaughter from feedlot steers fed a basal finishing diet $(n=6)$ or the basal diet supplemented with $3 \%$ palm oil $(n=6)$ or $3 \%$ soybean oil $(\mathrm{n}=6)$

\begin{tabular}{|c|c|c|c|c|c|c|c|c|c|c|}
\hline \multirow{2}{*}{$\begin{array}{l}\text { Fatty acid } \\
\text { (g/100 g total fatty acids) }\end{array}$} & \multicolumn{5}{|c|}{ Subcutaneous adipose tissue $^{1}$} & \multicolumn{5}{|c|}{ Intramuscular adipose tissue } \\
\hline & Control & Palm oil & Soybean oil & SEM & p-value & Control & Palm oil & Soybean oil & SEM & p-value \\
\hline $16: 0^{2}$ & 27.91 & 26.95 & 26.70 & 0.37 & 0.09 & 31.88 & 32.22 & 31.43 & 0.19 & 0.14 \\
\hline $16: 1 n-7^{3}$ & $5.00^{\mathrm{a}}$ & $3.73^{\mathrm{b}}$ & $4.30^{\mathrm{ab}}$ & 0.24 & 0.05 & 3.66 & 3.32 & 3.62 & 0.15 & 0.10 \\
\hline $18: 0^{2}$ & $10.43^{\mathrm{b}}$ & $12.55^{\mathrm{a}}$ & $12.58^{\mathrm{a}}$ & 0.54 & 0.02 & 14.72 & 15.00 & 14.82 & 0.47 & 0.39 \\
\hline $18: 1 n-9^{3}$ & 42.94 & 42.70 & 42.85 & 0.60 & 0.22 & 34.92 & 35.91 & 35.03 & 0.54 & 0.26 \\
\hline $18: \ln -7^{3}$ & $1.83^{\mathrm{a}}$ & $1.36^{\mathrm{b}}$ & $1.46^{\mathrm{b}}$ & 0.07 & 0.01 & $0.97^{\mathrm{a}}$ & $0.50^{\mathrm{b}}$ & $0.66^{\mathrm{ab}}$ & 0.09 & 0.04 \\
\hline $18: 2 n-6$ & 1.84 & 1.90 & 2.04 & 0.08 & 0.18 & 1.67 & 1.63 & 1.88 & 0.07 & 0.10 \\
\hline $18: 3 n-3^{3}$ & 0.08 & 0.07 & 0.10 & 0.01 & 0.22 & 0.02 & 0.01 & 0.01 & 0.01 & 0.17 \\
\hline $18: 2$ cis-9,trans $-11^{3}$ & 0.67 & 0.60 & 0.65 & 0.04 & 0.25 & 0.04 & 0.04 & 0.01 & 0.02 & 0.17 \\
\hline$A M P K \alpha$ & $2.78^{\mathrm{a}}$ & $2.19^{\mathrm{b}}$ & $2.46^{\mathrm{ab}}$ & 0.25 & 0.04 & 2.16 & 1.93 & 1.84 & 0.21 & 0.31 \\
\hline$C E B P \beta$ & $1.63^{\mathrm{ab}}$ & $1.14^{\mathrm{b}}$ & $2.72^{\mathrm{a}}$ & 0.35 & 0.03 & $1.51^{\mathrm{ab}}$ & $0.74^{\mathrm{b}}$ & $1.98^{\mathrm{a}}$ & 0.41 & 0.01 \\
\hline GPR43 & 2.99 & 3.83 & 3.08 & 0.92 & 0.24 & 3.50 & 4.89 & 1.65 & 1.06 & 0.17 \\
\hline$P P A R \gamma^{3}$ & 1.00 & 1.26 & 1.02 & 0.21 & 0.31 & 0.58 & 0.43 & 0.41 & 0.09 & 0.25 \\
\hline$S C D^{3}$ & $1.85^{\mathrm{a}}$ & $1.04^{\mathrm{ab}}$ & $0.66^{\mathrm{b}}$ & 0.14 & 0.05 & 0.08 & 0.13 & 0.04 & 0.03 & 0.16 \\
\hline
\end{tabular}

SEM, standard error of the mean; $A M P K \alpha$, AMP-activated protein kinase alpha; $C E B P \beta$, CCAAT enhancer binding protein- $\beta$; GPR43, G-coupled protein receptor 43; $P P A R \gamma$, peroxisome proliferator-activated receptor gamma; $S C D$, stearoyl-CoA desaturase.

${ }^{1}$ Data for subcutaneous adipose tissue derived from Choi et al. (2013).

${ }^{2}$ Intramuscular adipose tissue $>$ subcutaneous adipose tissue, $\mathrm{p}<0.05$ (data pooled across dietary treatments).

${ }^{3}$ Intramuscular adipose tissue $<$ subcutaneous adipose tissue, $\mathrm{p}<0.05$ (data pooled across dietary treatments).

${ }^{\mathrm{ab}}$ Means in rows not bearing a common superscript differ, $\mathrm{p}<0.05$. 
proportion of linoleic acid than control and palm oil-fed steers.

In samples collected at slaughter, $P P A R \gamma$ and $S C D$ gene expression was less in i.m. adipose tissue than in s.c. adipose tissue $(\mathrm{p}<0.05)$ (Table 6$)$, and $S C D$ mRNA was barely detectable in i.m. adipose tissue. Palm oil decreased $A M P K \alpha$ gene expression in s.c. adipose tissue $(\mathrm{p}=0.04)$. $C E B P \beta$ gene expression was higher in s.c. and i.m. adipose tissue of soybean oil-fed steers than in palm oil-fed steers and was intermediate in adipose tissues of control steers $(\mathrm{p} \leq 0.03)$. Soybean oil decreased $S C D$ gene expression in s.c. adipose tissue $(\mathrm{p}=0.05)$; $S C D$ gene expression in palm oilfed steers was intermediate between control and soybean oil-fed steers.

\section{DISCUSSION}

In a study with Korean Hanwoo cattle (Song et al., 2010), 7\% supplementary soybean oil (DM basis) depressed feed intake, ADG, and G:F, similar to results of the current study. However, Engle et al. (2000) earlier reported that 4\% supplementary soybean oil had no effect on ADG, ADI, or G:F, but depressed marbling scores, whereas Ludden et al. (2009) later reported that 5\% supplemental soybean oil had no effect on production or carcass traits of Gelbvieh $\times$ Angus cross bred steers. The previous studies and the current study differed in many aspects of experimental design, but in none of these studies did soybean oil increase ADG, G:F, or marbling scores.

Changes in plasma fatty acid composition indicated at least partial absorption of fatty acids provided by the oil supplements. The proportion of plasma palmitic acid was greatest in palm oil-fed steers and proportions of linoleic acid and $\alpha$-linolenic acid were greatest in the soybean oilfed steers at the intermediate and final sampling times. The increase in plasma PUFA in the soybean oil-fed steers indicated that at least a portion of these fatty acids escaped ruminal biohydrogenation. We expected plasma oleic acid to be elevated in response to palm oil supplementation, but this was not observed. Instead, there was no difference in the proportion of plasma oleic acid between the control and palm oil-fed steers, even though palm oil provided an additional $12 \mathrm{~g}$ oleic acid per $\mathrm{kg}$ of feed.

In plasma from the control and palm oil-fed steers, oleic acid steadily increased and linoleic acid decreased over time. It is not possible to discern from these data if these changes in plasma fatty acid composition reflected changes in hepatic fatty acid metabolism or ruminal biohydrogenation. Steers supplemented with soybean oil grew less efficiently, suggesting that the supplemental dietary PUFA in soybean oil were affecting ruminal fermentation. Conversely, the increase in plasma oleic acid could have been caused by a possible increase in hepatic SCD activity with time on feed, but we have not documented the effects of time on feed on $S C D$ gene expression or SCD activity in bovine liver.

Bovine s.c. adipose tissue is the primary site for fatty acid elongase and SCD activity in cattle (St. John et al., 1991; Archibeques et al., 2005), and the fatty acid elongase and $\Delta 9$ desaturase enzymes work in concert to convert palmitic acid first to stearic acid and subsequently to oleic acid. The elevation in adipose tissue stearic acid caused by palm oil is consistent with a rapid conversion of supplementary palmitic acid to stearic acid. Alternatively, palmitic acid can be desaturated to palmitoleic acid by SCD, and palmitoleic acid subsequently can be elongated to cisvaccenic acid. However, palm and soybean oil depressed the proportions of both palmitoleic acid and cis-vaccenic acid in s.c. adipose tissue. These data indicate that palm and soybean oil depressed $\Delta 9$ desaturation of palmitic acid, a conclusion that is consistent with the reduction in $S C D$ gene expression caused by the supplemental oils. Palm and soybean oil had lesser but similar effects on palmitoleic and cis-vaccenic acid in i.m. adipose tissue, although there was not a detectable effect of supplemental oils on $S C D$ gene expression in i.m. adipose tissue.

Joseph et al. (2010) reported that adding high levels of corn oil $(0.62 \mathrm{~kg} / \mathrm{d}$, or approximately $6 \%)$ to the diets of Angus steers depressed $S C D, P P A R \gamma, C E B P \alpha$, fatty acid synthase, and acetyl-CoA carboxylase gene expression, but increased lipoprotein lipase, and sterol regulatory elementbinding protein gene expression; these effects were attributed to the high concentration of linoleic acid in the corn oil. The decrease in $S C D$ gene expression and increase in $C E B P \beta$ gene expression we observed in s.c. adipose tissue taken slaughter in soybean oil-supplemented steers are similar to the results reported by Joseph et al. (2010) and provide additional support for the effects of dietary PUFA on adipose tissue gene expression during growth.

In these same cattle, we reported that, relative to palm oil, feeding $3 \%$ soybean oil to cattle decreased s.c. adipocyte size and the activities of NADP-malate dehydrogenase and glucose-6-phosphate dehydrogenase (Choi et al., 2013). In a separate study, we reported that the SFA palmitic acid and stearic acid strongly promoted $C E B P \beta$ and $C P T 1 \beta$ gene expression in i.m. preadipocytes (Choi et al., 2015), whereas oleic acid and linoleic acid depressed $S C D$ gene expression. We conclude that the depression in $S C D$ gene expression in s.c. adipose tissue of soybean oil-supplemented steers was caused by the high concentration of linoleic acid in soybean oil. Furthermore, supplemental palm oil did not significantly depress $S C D$ gene expression in this study, possibly because SFA in palm oil may attenuated the effects of oleic acid on $S C D$ gene expression in vivo (Choi et al., 2015).

At the intermediate sampling period, $A M P K \alpha$ and $C E B P \beta$ gene expression was numerically higher in s.c. 
adipose tissue of palm oil-fed steers than in adipose tissue from control or soybean oil-fed steers. Although not statistically significant, these data are similar to results with cultured preadipocytes, in which $A M P K \alpha$ and $C E B P \beta$ gene expression was higher in cultures containing supplemental SFA than in cultures containing unsaturated fatty acids (Choi et al., 2015). Underwood et al. (2007) reported lower AMPK phosphorylation in muscle that had abundant i.m. lipid than in muscle low in i. m. lipid. We cannot discern from this or our previous study of gene expression in adipose tissue of growing cattle (Smith et al., 2012) whether changes in $A M P K \alpha$ mRNA with age or supplemental oil treatment were associated with greater AMPK activity, as AMPK protein amount and phosphorylation were not measured. The current data indicate that the decline in $P P A R \gamma$ and SCD gene expression between d 35 and $\mathrm{d} 70$ was accompanied with a decrease in $A M P K \alpha$ gene expression as s.c. adipose tissue became less metabolically active in the older cattle. Similarly, the somewhat lower $A M P K \alpha$ gene expression in soybean oil-fed steers at the intermediate sampling point was consistent with an overall depression of adipose tissue metabolism by soybean oil.

We have demonstrated previously that PPAR $\gamma$ and $S C D$ gene expression and catalytic activity are in less in i.m. adipose tissue than in s.c. adipose tissue (Archibeque et al., 2005; Choi et al., 2013), and the same results for gene expression were observed in this study. SCD gene expression was barely detectable in i.m. adipose tissue, so it was not possible to demonstrate an effect of supplemental oils in this tissue. In a previous study, we demonstrated that $C E B P \beta$ and PPAR gene expression declined markedly between 14 and 16 mo of age, whereas GPR43 gene expression increased nearly 10 -fold and $S C D$ and $A M P K \alpha$ gene expression did not change during this period (Smith et al., 2012). Our previous (Martin et al., 1999; Smith et al., 2012) and current studies suggest that adipogenic gene expression declines in s.c. adipose during the late phases of carcass fattening. Similarly, gene expression associated with lipid filling of adipocytes (e.g., GPR43 gene expression) is elevated in fatter cattle, promoting additional carcass adiposity.

In conclusion, this study demonstrated that palm oil and soybean oil significantly affected gene expression in bovine s.c. and i.m. adipose tissues, consistent with our previous report on the effects of palm oil on lipid synthesis in vitro and carcass adiposity (Choi et al., 2013). However, contrary to original hypothesis, soybean oil more effectively depressed $S C D$ gene expression than palm oil in s.c. adipose tissue. In countries such as Korea in which palm oil is an agri-byproduct, palm oil may be a cost-effective feed additive. In the U.S., 33\% of feedlot nutritionists use plant oils as feed ingredients (Vasconcelos and Gaylean, 2007) but, because palm oil is not used in industrial food preparation, it is not available as an agri-byproduct. Thus, it may not be cost-effective as a feed ingredient in the USA.

\section{CONFLICT OF INTEREST}

We certify that there is no conflict of interest with any financial organization regarding the material discussed in the manuscript.

\section{ACKNOWLEDGMENTS}

Supported by funds from the Beef Checkoff, the Texas A\&M University/NSF-China collaborative research program, and the Rural Development Administration, Korea, PJ01091003.

\section{REFERENCES}

Adams, T. H., R. L. Walzem, D. R. Smith, S. Tseng, and S. B. Smith. 2010. Hamburger high in total, saturated and trans-fatty acids decreases HDL cholesterol and LDL particle diameter, and increases TAG, in mildly hypercholesterolaemic men. Br. J. Nutr. 103:91-98.

Archibeque, S. L., D. K. Lunt, C. D. Gilbert, R. K. Tume, and S. B. Smith. 2005. Fatty acid indices of stearoyl-CoA desaturase do not reflect actual stearoyl-CoA desaturase enzyme activities in adipose tissues of beef steers finished with corn-, flaxseed-, or sorghum-based diets. J. Anim. Sci. 83:1153-1166.

Brown, A. J., S. M. Goldsworthy, A. A. Barnes, M. M. Eilert, L. Tcheang, D. Daniels, A. I. Muir, M. J. Wigglesworth, I. Kinghorn, N. J. Fraser, N. B. Pike, J. C. Strum, K. M. Steplewski, P. R. Murdock, J. C. Holder, F. H. Marshall, P. G. Szekeres, S. Wilson, D. M. Ignar, S. M. Foord, A. Wise, and S. J. Dowell. 2003. The Orphan G protein-coupled receptors GPR41 and GPR43 are activated by propionate and other short chain carboxylic acids. J. Biol. Chem. 278:11312-11319.

Cao, Z., R. M. Umek, and S. L. McKnight. 1991. Regulated expression of three C/EBP isoforms during adipose conversion of 3T3-L1 cells. Genes Dev. 5:1538-1552.

Choi, S. H., G. O. Gang, J. E. Sawyer, B. J. Johnson, K. H. Kim, C. W. Choi, and S. B. Smith. 2013. Fatty acid biosynthesis and lipogenic enzyme activities in subcutaneous adipose tissue of feedlot steers fed supplementary palm oil or soybean oil. J. Anim. Sci. 91:2091-2098.

Choi, S. H., S. K. Park, B. J. Johnson, K. Y. Chung, C. W. Choi, K. H. Kim, W. Y. Kim, and B. Smith. 2015. $A M P K \alpha, C / E B P \beta$, $C P T 1 \beta, G P R 43, P P A R$, and $S C D$ gene expression in singleand co-cultured bovine satellite cells and intramuscular preadipocytes treated with palmitic, stearic, oleic, and linoleic acid. Asian Australas. J. Anim. Sci. 28:411-419.

Chung, K. Y., D. K. Lunt, H. Kawachi, H. Yano, and S. B. Smith. 2007. Lipogenesis and stearoyl-CoA desaturase gene expression and enzyme activity in adipose tissue of short- and long-fed Angus and Wagyu steers fed corn- or hay-based diets. J. Anim. Sci. 85:380-387.

Duckett, S. K., S. L. Pratt, and E. Pavan. 2009. Corn oil or corn grain supplementation to steers grazing endophyte-free tall 
fescue. II. Effects on subcutaneous fatty acid content and lipogenic gene expression. J. Anim. Sci. 87:1120-1128.

Engle, T. E., J. W. Spears, V. Fellner, and J. Odle. 2000. Effects of soybean oil and dietary copper on ruminal and tissue lipid metabolism in finishing steers. J. Anim. Sci. 78:2713-2721.

Ge, H., X. Li, J. Weiszmann, P. Wang, H. Baribault, J. L. Chen, H. Tian, and Y. Li. 2008. Activation of G protein-coupled receptor 43 in adipocytes leads to inhibition of lipolysis and suppression of plasma free fatty acids. Endocrinology 149:4519-4526.

Gilmore, L. A., R. L. Walzem, S. F. Crouse, D. R. Smith, T. H. Adams, V. Vaidyanathan, X. Cao, and S. B. Smith. 2011. Consumption of high-oleic acid ground beef increases HDLcholesterol concentration but both high- and low-oleic acid ground beef decrease HDL particle diameter in normocholesterolemic men. J. Nutr. 141:1188-1194.

Gilmore, L. A., S. F. Crouse, A. Carbuhn, J. Klooster, J. A. Calles, T. Meade, and S. B. Smith. 2013. Exercise attenuates the increase in plasma monounsaturated fatty acids and highdensity lipoprotein cholesterol but not high-density lipoprotein $2 \mathrm{~b}$ cholesterol caused by high-oleic ground beef in women. Nutr. Res. 33:1003-1011.

Hardie, D. G. 2007. Biochemistry. Balancing cellular energy. Science 315:1671-1672.

Joseph, S. J., S. L. Pratt, E. Pavan, R. Rekaya, and S. K. Duckett. 2010. Omega-6 fat supplementation alters lipogenic gene expression in bovine subcutaneous adipose tissue. Gene Regul. Syst. Bio. 19:91-101.

Kimura, I., K. Ozawa, D. Inoue, T. Imamura, K. Kimura, T. Maeda, K. Terasawa, D. Kashihara, K. Hirano, T. Tani, T. Takahashi, S. Miyauchi, G. Shioi, H. Inoue, and G. Tsujimoto. 2013. The gut microbiota suppresses insulin-mediated fat accumulation via the short-chain fatty acid receptor GPR43. Nat. Commun. 4:1829.

Ludden, P. A., O. Kucuk, D. C. Rule, and B. W. Hess. 2009. Growth and carcass fatty acid composition of beef steers fed soybean oil for increasing duration before slaughter. Meat Sci. 82:185-192.

Martin, G. S., D. K. Lunt, K. G. Britain, and S. B. Smith. 1999. Postnatal development of stearoyl coenzyme A desaturase gene expression and adiposity in bovine subcutaneous adipose tissue. J. Anim. Sci. 77:630-636.

NRC. 2000. Nutrient Requirements of Beef Cattle. 7th rev. ed. National Academy Press, Washington, DC, USA.
Smith, S. B., A. Yang, T. W. Larsen, and R. K. Tume. 1998. Positional analysis of triacylglycerols from bovine adipose tissue lipids varying in degree of unsaturation. Lipids 33:197207.

Smith, S. B., G. W. Go, B. J. Johnson, K. Y. Chung, S. H. Choi, J. E. Sawyer, D. T. Silvey, L. A. Gilmore, G. Ghahramany, and K. H. Kim. 2012. Adipogenic gene expression and fatty acid composition in subcutaneous adipose tissue depots of Angus steers between 9 and 16 months of age. J. Anim. Sci. 90:25052514.

Smith, S. B., H. Kawachi, C. B. Choi, C. W. Choi, G. Wu, and J. E. Sawyer. 2009. Cellular regulation of bovine intramuscular adipose tissue development and composition. J. Anim. Sci. 87(14 Suppl):E72-82.

Song, M. K., G. L. Jin, B. J. Ji, S. S. Chang, J. Jeong, S. B. Smith, and S. H. Choi. 2010. Conjugated linoleic acids content in M.longissimus dorsi of Hanwoo steers fed a concentrate supplemented with soybean oil, sodium bicarbonate-based monensin, fish oil. Meat Sci. 85:210-214.

St. John, L. C., D. K. Lunt, and S. B. Smith. 1991. Fatty acid elongation and desaturation enzyme activities of bovine liver and subcutaneous adipose tissue microsomes. J. Anim. Sci. 69:1064-1073.

Tontonoz, P., E. Hu, R. A. Graves, A. I. Budavari, and B. M. Spiegelman. 1994. mPPAR gamma 2: tissue-specific regulator of an adipocyte enhancer. Genes Dev. 8:1224-1234.

Underwood, K. R., J. Tong, M. J. Zhu, Q. W. Shen, W. J. Means, S. P. Ford, S. I. Paisley, B. W. Hess, and M. Du. 2007. Relationship between kinase phosphorylation, muscle fiber typing, and glycogen accumulation in longissimus muscle of beef cattle with high and low intramuscular fat. J. Agric. Food Chem. 55:9698-9703.

Vasconcelos, J. T. and M. L. Galyean. 2007. Nutritional recommendations of feedlot consulting nutritionists: the 2007 Texas Tech University survey. J. Anim. Sci. 85:2772-2781.

Wan, Z., J. Root-McCaig, L. Castellani, B. E. Kemp, G. R. Steinberg, and D. C. Wright. 2014. Evidence for the role of AMPK in regulating PGC-1 alpha expression and mitochondrial proteins in mouse epididymal adipose tissue. Obesity (Silver Spring) 22:730-738.

Westerling, D. B. and H. B. Hedrick. 1979. Fatty acid composition of bovine lipids as influenced by diet, sex and anatomical location and relationship to sensory characteristics. J. Anim. Sci. 48:1343-1348.

Yin, W., J. Mu, and M. J. Birnbaum. 2003. Role of AMP-activated protein kinase in cyclic AMP-dependent lipolysis In 3T3-L1 adipocytes. J. Biol. Chem. 278:43074-43080. 